\title{
MEDICAL MALPRACTICE \\ LITIGATION: DO WE NEED A PARADIGM SHIFT IN OUR APPROACH TO HANDLING MEDICAL NEGLIGENCE DISPUTES?*
}

\author{
Dr Henry Lerm \\ Dip (Industrial Admin) B Proc. LLB LLM LLD \\ Admitted Attorney and Justice Centre Executive \\ for the Uitenhage Justice Centre \\ Director and Chairperson for the Eastern Cape \\ Branch of the South African Medico Legal \\ Association
}

\section{SUMMARY}

This article takes a critical look at the current state of affairs of both our public as well as private healthcare sectors in South Africa. The focus of this article is to try and find reasons for the exorbitant amounts of monies spent on litigation, which our country can ill afford. What will be considered is whether we need a paradigm shift in our approach to handling medical negligence disputes? What will also be introduced as part of the suggested solutions are practices that can be put in place. It is especially the introduction of mediation as oversight mechanism and other practices that will receive wide attention.

\section{$1 \quad$ INTRODUCTION}

South Africa today is facing a devastating crisis in both our public as well as private healthcare sectors, with medical malpractice litigation spiralling out of control. Concerns are frequently raised about large amounts being spent from the public purse to fund cases in the public sector and the high-value claims encountered in the private sector. Childbirth cases, for example, can run into millions of Rand. That has caused Dr Motsoaledi, the Minister of Health, to accuse lawyers of unnecessarily fuelling litigation. ${ }^{1}$ This paper investigates the conduct of lawyers when approaching medical negligence disputes. What is also placed under the microscope is the behaviour of

\footnotetext{
Paper presented by Dr Henry Lerm at a colloquium on the state of healthcare in South Africa organized by the South African Medico-Legal Association in Port Elizabeth (21 May 2016).

1 Evans "Lawyers Targeting Doctors after RAF Shake-up-Motsoaledi" 14 February 2016 News24 http://www.news24.com/SouthAfrica/News/lawyers-targeting-doctors-after-rafshake-up-motsoaledi (accessed 2016-02-15).
} 
healthcare practitioners when facing clinical medical negligence litigation. In addition, looking at the present state of our healthcare sectors, this paper also accentuates key areas that have influenced both sectors. Although there are multitudes of factors, the following seem to be the most salient. Lawyers exploit the adversarial system, often for self-gain. The lack of meaningful communications between attorney and client and healthcare provider and patient, especially after something had gone wrong, is often the cause of litigation. The pre-litigation stage offers very little to resolve disputes. Even though case management directives aim to reduce mounting litigation costs, lawyers are loathe to follow them. This paper recognises the growing need for legal reform. What is suggested is a system that will ensure compensation is paid to worthy claimants, and where settlements are not possible, to curb costs as much as possible.

\section{PRESENT STATE OF AFFAIRS IN SOUTH AFRICA}

\section{The Public Healthcare Sector}

The contingent liabilities in respect of medico-legal claims around the country are quite startling. It is believed that the Eastern Cape Department of Health is the highest sued department with R11 billion. ${ }^{2}$ This is followed by the Gauteng Provincial Health Department, the total quantum of damages being claimed amounting to R6.5 billion. Even the Free State Department of Health is facing medical malpractice claims to the value of R700 million. ${ }^{3}$ It is estimated that health departments across the country spend in excess of R3 billion on legal costs payable to claimants' lawyers. It is also believed that no budgets for those expenses exist. Consequently, payments are being made from funds designated for medical equipment and other purposes. The irony is that because of those unexpected pay outs, old and often faulty equipment cannot be renewed or upgraded, resulting in even further claims attributable to faulty equipment.

\section{The Private Healthcare Sector}

The private healthcare sector is no better off. Physicians in the private sector feel vulnerable, as they believe they are targeted. Here, gynaecologists followed by neurosurgeons and plastic surgeons are the most vulnerable. ${ }^{4}$ The Medical Protection Society has also confirmed an increase of $550 \%$ in medical malpractice claims against members, compared to 10 years ago.

2 Mbengashe The State of the Healthcare in the Public Sector in the Eastern Cape and the Impact of Medico-Legal Litigation in the Sector. Paper presented at an inaugural seminar organized by the South African Medico-Legal Association in East London (28 November 2015) 2.

3 Lotriet "Free State Hospitals Swamped by Malpractice Cases" 20 May 2015 News24 http://www/news24.com/SouthAfrica/News/Free-State-hospitals-swamped-by-malpracticecases (accessed 2016-02-15).

4 Evans 14 February 2016 News24. 
The amount of claims that exceed R5 million in quantum per claim also increased by $90 \%{ }^{5}$

Some of the biggest causes encountered by this include:

- Exorbitant increases in insurance premiums are resulting in some highrisk specialists leaving the medical profession. ${ }^{6}$

- Junior doctors are discouraged from entering specialised fields.

- It has prompted practitioners to practice defensive medicine resulting in an increase in the costs of medical care.

- Doctors and/or specialists have to spend so much time away from their surgeries or operating theatres defending the claims against them. Instead, they face the cold comfort of courtrooms.

- South Africa is losing highly qualified and experienced experts to other countries where either insurance premiums are more reasonable, or they are less likely to be plagued by unfounded lawsuits.

What is also quite disturbing is this: those who elect to institute proceedings against healthcare providers are not always successful. On the contrary, the majority are either unsuccessful at the hearing or are withdrawn before the matter goes on trial. ${ }^{7}$ Some of the contributing factors to this eventuality include:

- The extent of medical malpractice litigation is not in keeping with generally known trends of negligence or malpractice. ${ }^{8}$ There are many instances where there is no prima facie negligence, which means that a plaintiff will not be able to prove his or her case. Some attorneys pursue claims in the hope that some offer of settlement will be forthcoming;

- Medicine is not an exact science. Although at first glance, the claim seems to be meritorious, upon closer scrutiny only a small percentage of cases are proved to be caused by negligence. Defences often raised with a certain degree of success, include medical mishaps and errors of judgment, which is often the case, even though it may seem to the populace in general that their conduct was wrong (as opposed to wrongful in law);

5 Botes "Mediation: A Perfect Solution to Healthcare Disputes" 2015 De Rebus 23; see also Pepper and Slabbert "Is South Africa on the Verge of a Medical Malpractice Storm?" 20114 $S A J B L$ 29; see further Malherbe "Counting the Cost: The Consequences of Increased Medical Malpractice Litigation in South Africa" 2013 103(2) SAMJ 2 http://www/samj. org.za/index.php/samj/article/view/6457/4857 (accessed 2016-02-12).

6 Howarth, Goolab, Dunn, Fieggen "Public Somnambulism: Public Lack of Awareness of the Consequences of Increasing Medical Negligence Litigation" 2014 104(ii) SA Med J 752753.

7 Van den Heever and Lawrenson Expert Evidence in Clinical Negligence: A Practitioner's Guide (2015) 97; Walters "Medical Malpractice Litigation: Is there an Alternative?" 2013 12(3) SA Orthopaedic Journal.

8 Motsoaledi "SA's Shocking Medical Malpractice Crisis" 9 March 2015 News24 www.health24.com/News/Public-Health/SAs-shocking-medical-malpractice-crisis-20150309. 


\section{- Proving causation can pose profound challenges. ${ }^{9}$}

However, the question may be begged is whether the lay public really understands the difference between negligence and the factors influencing medical negligence? The suggested answer is, "not really". Besides searching on the internet, their trusted friend, sharing information with them, generally neither their lawyers nor their health practitioners spend sufficient time with their clients or patients informing them of their position and what may be expected. That poses a real dilemma to the person upon whom harm is brought.

In turn, this lack of qualified and correct information has a twofold effect. Firstly, from a legal perspective, unless the risks of litigation are laid bare and the intervening factors, that is, defences that may influence successful outcomes are fully explained, the client, a lay person, may be under a misapprehension about the prospect of "winning their cases". A negative outcome, often accompanied by adverse cost orders, would be met by the utmost devastation. The protracted time spent on litigation is viewed as a complete waste of time.

Secondly, the failure of the health practitioner to inform their patients of the possible causes leading to the undesired results, do not sit well with the lay public. Studies have shown that the majority of complaints brought against healthcare practitioners and the litigation that may follow are caused by a lack of communication between the practitioner and the patient. ${ }^{10}$ Because patients are not adequately informed about what may possibly have gone wrong and so, appreciate the consequences of surgery or the possibility of complications that bring a risk, post operatively patients view the conduct of their practitioners with suspicion.

Yet, the irony is sometimes found in patients just wanting to be listened to instead of necessarily resorting to suing the hospital or healthcare providers. To this end, what some patients seek are for their non-financial needs to be fulfilled. An apology by the practitioner and an undertaking to take remedial action and not to repeat the mistake again may be good enough for some. Many a client has been heard mentioning that they do not necessarily want anything but just to make sure that this does not happen to someone else.

What makes matters worse is that more than $90 \%$ of all litigated matters are settled out of court, most of them virtually on the courts' steps, years after commencement. The long wait to have their disputes with those whom they once trusted but have now ended up in acrimonious relationships with, resolved, bring about much trauma and anxiety for both patients and healthcare providers.

Then there is a huge reputational risk amongst the healthcare professionals facing these civil claims. It often leads to fear and despair. A loss of self-worth and confidence may impact heavily on their family life and have a negative effect on their professional careers.

9 Dutton The Practitioner's Guide To Medical Malpractice in South African Law (2015) 59 with the host of reported cases quoted in $\mathrm{fn} 2$ therein; see also Van den Heever and Lawrenson Expert Evidence in Clinical Negligence: A Practitioner's Guide 95.

10 Walters 2013 12(3) SA Orthopaedic Journal. 
Doctors and nurses are also not keen to speak to patients afterwards or tender an apology for a mishap that occurred. Even if they were desirous of so doing, our judicial adversarial system does not approve of that. Nor are the representatives of the opposing parties encouraged to speak freely with each other save for pre-trial conferences, etc. Healthcare providers may also be under their attorneys', insurers' or protection societies' starters' orders, prohibiting them from communicating with anyone, save with their lawyers and insurer about the incident. ${ }^{11}$ This leads to the start of the acrimonious relationship and reason for litigation. Given the nature of the acrimony and duration of the litigation, it is unlikely that the relationship between the healthcare provider and patient will ever be restored.

What our adversarial system does, is to expose the parties to a formalistic and time-consuming process, with very little prospect of early settlements and often at substantial legal costs. Much of the money spent accrues to the lawyers in contingency fee arrangements, sometimes in excess to what the law allows. ${ }^{12}$ This is depleting State coffers, posing a serious challenge to medicine in South Africa. It will be contended in this paper that the monies spent in that way, can rather be utilised to improve health services.

Now that we have identified some of the contributing factors that make the system governing medical malpractice litigation less desirable, it will be contended that litigation in this way, does raise a number of interesting ethical and policy issues. Some of the concerns expressed are in need of urgent attention by our policy makers, responsible for safeguarding healthcare.

This paper also takes a cursory glance at the implementation of a number of practices designed to allow for a paradigm shift in our approach to medical negligence disputes. They include:

$>$ introducing the practice of certification;

$>$ the establishment of specialist medical courts, alternatively the introduction of expert assessors in medical malpractice trials;

$>$ the strict adherence to pre-trial conferences and trial management procedures;

$>$ an early apology and remedial action, cultivating the idea that an apology does not amount to admitting negligence or fault;

$>$ introducing mediation as an oversight mechanism to handle medical negligence disputes;

11 See Carstens and Pearmain Foundational Principles of South African Medical Law (2007) 270 with reference to the directives of the Medical Protection Society (MPS) and the Medical Defence Union (MDU) and the advice penned by Strauss Doctor, Patient and the Law (1997) 370. Contra however, the MPS's recently released paper on clinical negligence reform titled "Challenging the Cost of Clinical Negligence, The Case For Reform" November 2015. This paper advocates a paradigm shift in the traditional non-disclosure to a culture of open and honest disclosure with patients when things go wrong.

12 See the Contingency Fees Act 66 of 1997; see also Ronald Bobroff and Partners Inc v De La Guerre; South African Association of Personal Injury Lawyers v Minister of Justice and Constitutional Development 2014 (3) SA 134 (CC); Graham v Law Society, Northern Provinces 2016 (1) SA 279 (GP). 
I am mindful of the fact that some of the ideas that follow may appear to be alien, even revolutionary and that some of the proposed practices in this paper have to a large degree, not been tested in South Africa. There are also those that have been part of our legal system but require modification or fine tuning, especially in light of the fact that medicine is a complicated subject.

The relevant reforms suggested are merely based, to a large degree, on theoretical predictions and keen scholarship and not necessarily expert knowledge. What must however, be borne in mind is this: the suggested practices were once the subject of much debate elsewhere but have become naturalised in many jurisdictions ${ }^{13}$ around the globe.

\section{IMPLEMENTATION OF PRACTICES DESIGNED FOR A POSSIBLE PARADIGM SHIFT}

\section{(i) Introducing the practice of certification}

The practice of filing a certificate of merit in medical malpractice litigation was introduced in a number of states in the United States of America in 2003. Its introduction came about in an effort to decrease frivolous medical malpractice cases instituted against healthcare providers. The certificate of merit also serves as a screening mechanism so that healthcare practitioners cannot raise defences that are without merit. Several states have since adopted the practice by incorporating it in their Civil Procedure Rules. ${ }^{14}$

The procedure of filing the certificate of merit works as follows. The plaintiff at the time of instituting an action or soon thereafter is required to file an affidavit certifying that a qualified medical expert believes that there is a "reasonable and meritorious" cause to bring the action. The expert is key to this early screening process. Only those experts accredited to do this type of work, would be eligible and their affidavits or opinions allowed.

The content of the affidavit could vary from being a simple statement namely, the expert had reviewed the medical record and found that there was sufficient evidence indicating a deviation from the required standard of care alternatively, a detailed opinion concerning the deviation from the standard of care and the causality aspect. ${ }^{15}$

Similarly, the defendant needs to file a certificate of merit in the form of an affidavit setting out his or her reasonable grounds for defending the action, supported by an expert's opinion.

13 MPS Paper on clinical negligence reform. It is particularly countries such as Australia and the United States of America where significant tort reform was introduced in the last two decades. The reform came as a result of a similar healthcare crisis they faced relating specifically to medical negligence.

14 Mello and Kachalia Evaluation of Options for Medical Malpractice System Reform 2010 Report prepared by the Harvard School for Public Health for the Medicare Payment Advisory Commission (Med PAC) 10.

15 Ibid. 
In certain States in the US, if the certificate of merit is not filed or is rejected for want of merit, it is the end of the road for the plaintiff. ${ }^{16}$ There are certain States that allow corrective action to cure the defect but it comes at a price for lawyers who do not comply. Adverse cost orders may very well be granted against those who do not comply with the rules. ${ }^{17}$

This may also discourage attorneys taking on matters where they are uncertain whether they would be able to obtain such an affidavit or opinion from a certified expert, alternatively cause them to obtain such affidavits or opinions before advising a client to commence action, thus saving the client from possible adverse legal cost orders for the institution of unfounded claims.

This paper advocates that a similar practice or modified version to suit our milieu, be investigated for South Africa. Our courts have on a number of occasions demonstrated that they would not hesitate to grant cost orders against those, including lawyers who abuse the process. ${ }^{18}$ This is where the courts should be encouraged to transform the legal profession to become more virtuous in its approach to handle medical negligence disputes.

\section{(ii) Introducing a system of peer review}

What goes hand in hand with the suggested practice of certification, especially in respect of the defendant healthcare practitioner, is a system of peer review. Here, a panel of doctors or physicians is appointed shortly after the doctor or physician has received notice of the intended action against him or her. The panel together with the lawyer designated to assist the doctor or physician will assess his or her conduct. The outcome will be shared with the doctor or physician involved, as well as some of his or her peers. This is also referred to as a "medical errors reporting system", ${ }^{19}$ alternatively a "patient-centred complaints system". ${ }^{20}$

The value of the proposed practice is threefold. Firstly, if it is established that negligence was present that causally contributed towards the damages suffered by the patient, the matter can be resolved very quickly. An offer can be made without resorting to litigation. An opinion may also be obtained from counsel where necessary. Secondly, where no negligence can be attributed to the doctor or physician's conduct, it will be so conveyed to him or her. That, in turn, will vindicate the doctor or physician and bring much relief to

16 Mello and Kachalia report by the Harvard School for Public Health for the Medicare Payment Advisory Commission (Med PAC) 11.

17 MPS Paper on clinical negligence reform.

18 See Schneider NO v AA 2010 (5) SA 203 (WCC) 219 210; L v MEC for Health, Gauteng [2014] ZA GPJHC 337 par 80-83; Mokhethi v MEC For Health, Gauteng 2014 (1) SA 93 par 26.

19 Marian "Changing Paradigms in the Field of Medical Malpractice: The Full Disclosure-Early Pay Approach" 12 February 2010 http://www.randalltitus.co.za/?p=166 (accessed 2016-0216). The writer expresses the view that the medical errors reporting system serves to educate the medical fraternity and so improve the quality of care and patient safety. See also Kevin "Open Dialogue on Medical Malpractice and Patient Safety" 7 December 2010 http://www.kevinmd.com/blog/2010/12/open-dialogue-medical-malpractice-patient-patient. html (accessed 2016-02-16).

20 MPS Paper on clinical negligence reform. 
him or her that has suffered much anxiety with the ordeal of being accused of malpractice. Thirdly, the peer review exercise serves as a learning curve to other practitioners. Where any shortcoming in protocols or practices are identified, corrective action in a hospital or otherwise can be taken the purpose of which is to improve health services. The patient will also be notified of the prospects of success and where the merit does not favour the plaintiff, he or she will think twice before instituting the action. ${ }^{21}$

The advantages of this kind of practice also include the fact that the early detection of baseless or frivolous litigation will reduce healthcare costs. This can be achieved through cost penalties being slapped on parties who pursue unmeritorious claims.

It may further be said that this type of peer review is not untenable in South Africa due to resources. Meetings regarding incidents in hospitals, which may open the hospital to liability, are already internally conducted by its administration upon a complaint being received. The same could potentially be opened or repeated with independent peers, on a without prejudice basis, in order to review the conduct, at a fraction of the cost of litigation. Disciplinary action against staff members related to patient care may also act as a proverbial "red light".

\section{(iii) Establishing specialist medical courts, alternatively, introducing expert assessors}

The ever-increasing skills of humankind through experience and education have brought about advances in both technological and scientific knowledge in various disciplines. This has resulted in those who, through their skills, interests and the application thereof, have become experts in their respective disciplines.

In medicine, the conduct of medical practitioners involved in litigation in South Africa is decided upon by a court comprised of a judge or magistrate on the views of experts in the field of medicine. ${ }^{23}$ Huge concerns may be raised in this regard, namely, whether judges and magistrates responsible for deciding medical negligence matters possess the necessary expertise and technical skills to match those of the experts testifying in trials before them.

Put differently, are they sufficiently equipped to follow the proceedings and proficiently, without delay, adjudicate often very complex matters before them? This paper suggests that they are not always endowed with sufficient knowledge and the necessary skills. What is mooted are changes to our present justice system through the introduction of specialist medical courts, alternatively the appointment of skilled assessors to assist the magistrates or judges.

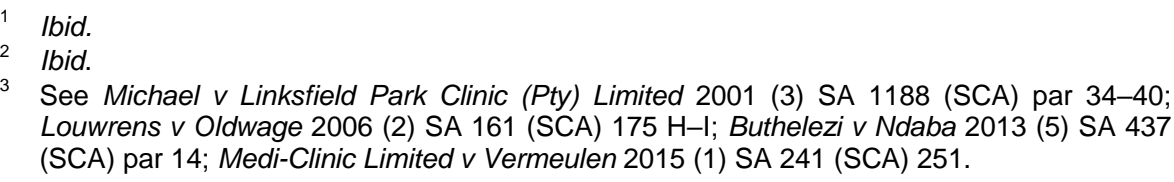




\section{Specialist medical courts}

Owing to magistrates and judges only being professionally trained as lawyers, sometimes only in say the field of criminal law or perhaps, in commercial law, they often lack the expertise, technical and scientific knowhow to match those of the experts who testify in cases before them. That in itself poses inherent drawbacks in the adjudication of medical negligence cases by the court. Allied to that is the fact that the law, like medicine, is an inexact science and sometimes full of uncertainties. It may be in the interests of the administration of justice to consider creating specialists courts designated to deal with medical negligence cases. ${ }^{24}$

The idea of establishing specialist courts is not an alien concept in South Africa. Those known in South Africa are inter alia the Income Tax Court, the Water Tribunal, as well as the Military Court. They have been established to handle specific areas of law or types of cases that are complex and some form of expertise is required.

What is envisaged is that those specialist Medical courts should sit in the High Court and hear only those matters that could not be resolved through a mediation process. The courts should be headed by judges chosen because of their skill in medical law and ethics as well as a good workable knowledge about medico-legal practices and procedures. Extramural training courses and experience on the bench will go a long way to acquire those. Besides the judge being assisted by an accredited medical expert in the field or discipline from where the dispute arises, no change in the court procedure is envisaged.

Establishing specialists courts will benefit both the victims of medical negligence cases as well as medical professionals in that judges with the required medical negligence expertise, will fully understand the technical complications and intricacies related to medical negligence cases.

This will enable the courts to dispose of those matters expeditiously and without unnecessarily burdening the parties with additional costs occasioned by a bevy of expert witnesses that are sometimes unnecessary. ${ }^{25}$ Because of the quality of judgments, fewer matters will be taken on appeal. It is also contended that the operation of a specialist court to handle medical negligence disputes is a better proposition than bringing those disputes to the Tribunals envisaged by the Consumer Protection Act ${ }^{26}$ as such Tribunals will face the same challenges as the courts, relating to medical knowledge and expertise.

24 The Supreme Court in India in the case of Martin F D'Souza v Mohd Ishfaq (civil appeal no 3441/2002 decided on 17 February 2009) par 34 describes the position as follows: "The law, like medicine, is an inexact science. One cannot predict with certainty an outcome of many cases. It depends on the particular facts and circumstances of the case, and also the personal notions of the Judge concerned who is heading the case. However, the broad and general legal principles relating to medical negligence need to be understood." 25 Kanoon and Kamdar "Judicial Interpretation of Medical Negligence in India" 15 August 2012 02-16).

26 See s 115 of the Consumer Protection Act 68 of 2008. 


\section{Skilled assessors as experts}

Where the establishing of specialist courts are not possible, it is then suggested that, our policy makers urgently pay attention to introduce a practice in terms of the Rules of Court whereby skilled assessors are appointed to assist judges and magistrates in complex matters. Medical negligence matters are most suited for this practice. Besides assisting in curbing legal costs, it will also raise the bar in public confidence in the justice system.

It is not a new idea. The first traces of this practice can be found in the Supreme Court of the Cape in the 1820s. The governor at the time chose to sit with assessors in civil matters. He was to be quite severely criticised when abandoning this practice. ${ }^{27}$ Despite this vacuum in our law, there is sufficient authority for us to adopt this practice by virtue of our High Court's inherent jurisdiction. ${ }^{28}$ The South African Constitution also serves as an auxiliary resource in amplifying the inherent jurisdiction of the High Court. ${ }^{29}$

Internationally, this practice has also found roots in many other jurisdictions. Its origin in England can be traced back to the 1930s and 1940s when judges in medical and admiralty matters would appoint expert assessors to advise them on technical medical and nautical issues. ${ }^{30}$ England has since the recommendations of the Woolf Commission, ${ }^{31}$ put rules in place to appoint skilled assessors in complex matters in their High Courts. ${ }^{32}$ The practice has also been adopted in countries like Australia, New Zealand and even Namibia.

\section{(iv) Strict adherence to pre-trial conferences and trial management procedures}

We are also living in a society where legal costs have become so enormously expensive that access to justice for the poor and the middle class are not within reach. To overcome that, the creation of a pre-trial conference system aided by a case management system is essential. This accord with initiatives put in place by policy makers, including the Chief Justice $^{33}$ and the Judge Presidents ${ }^{34}$ of various divisions of the High Courts.

27 Farlam "The Origin of the Cape Bar" 19881 Consultus.

8 Harms Civil Procedure in Supreme Courts (2002) A-7ff; see also Taitz The Inherent Jurisdiction of the Supreme Court (1986) 8ff; see further Lerm "Two Heads Are Better Than One: Assessors in High Court Civil Cases" 2012 De Rebus 22-24.

29 S 173 of the Constitution Act 108 of 1996. S 173 of the Constitution provides inter alia that the High Courts have an inherent power "to protect and regulate their own processes".

30 Richardson $v$ Redpath Brown and Co (Pty) Ltd (1944) AC 62, 70 and The Tovarich (1931) AC 105.

31 See Woolf Access to Justice Final report to the Lord Chancellor on the Civil Justice System in England and Wales, HMSO, London July 1996 140-142 151.

32 See Rule 35.15 of the Civil Procedure Rules (October 2009) United Kingdom.

33 See the Norms and Standards issued under the hand of the Chief Justice of the Republic of South Africa in terms of $s 8$ of the Superior Court Act 10 of 2013 read with s 165 (6) of the Constitution and published in the GG 37390 on 28 February 2014. The objective of the norms and standards are for inter alia the judicial officers "[t]o ensure access to quality justice: to affirm the dignity of all users of the court system and to ensure the effective, 
The whole idea behind those initiatives is to define the triable issues so as to curtail proceedings in an endeavour to curb litigation costs.

A precursor to the success of pre-trial conferences and case management systems is the earnestness and seriousness at which lawyers and other role players, including judges, approach and commit themselves to the processes. It is here that lawyers in South Africa need to make a paradigm shift. What is needed is a shift in mindset to make them work. Instead of treating the processes as a tick box method of complying, lawyers need to commit themselves to further the interests of their clients instead of their own in protracting matters to earn more fees. Judges should also be more committed to making the process work. Here they need to keep the parties to time limits along with strict control of postponements. They need to impose sanctions on non-compliant parties.

An area of particular significance is the role of experts in the preparation for the trial. Currently, the court rules do not mandate experts' meetings or experts' joint minutes as part of the claims process. ${ }^{36}$ The introduction of early experts' meetings and compiling joint minutes of the experts are fundamental to the endeavour to settle the dispute between the parties, alternatively, failing settlement, to define their differences which ultimately makes the adjudication process of the presiding judge or magistrate easier.

It is here where the role of a skilled assessor appointed for the trial, may assist the judge or magistrate during the early stages of the said conferences and pre-trial hearings. An all-important function of the skilled assessor is to assist the expert witnesses in narrowing the issues down and to get the case trial ready. They will also play an oversight role in the experts producing effective joint minutes.

\section{(v) An early apology and remedial action}

The patient's lack of medical knowledge and the doctor or hospital authority's failure to give an explanation about what had possibly gone wrong often fuels suspicion and eventually anger. Moreover, all the patient sometimes wants is an explanation. That, together with an apology might in some instances, even influence the patient or family not to sue. ${ }^{37}$

Studies in the United States of America have shown that a failure to tender an explanation besides being viewed, as a lack of empathy, has been

efficient and expeditious adjudication and resolution of all disputes... These objectives can only be attained through the commitment and co-operation of all judicial officers in keeping with their oath or solemn affirmation to uphold and protect the Constitution..."

34 See the Practice Notes of the various divisions of the High Courts in the Western Cape, North Gauteng and South Gauteng. The whole idea about setting out the Practical Notes is "to improve the efficiency of the judicial system through the application of effective pre-trial and case management systems".

35 MPS Paper on clinical medical negligence reform.

36 Ibid.

37 Mulcahy "Mediating Medical Negligence Claims" September 2000 Amicus Curiae Issue 10; see also Marian http://www.randalltitus.co.za/?p=166 15. 
the cause found for the vast majority of medical negligence lawsuits. ${ }^{38}$ An apology at the right time may thus serve as a catalyst in the acrimonious relationship between healthcare provider and patient, leading up to litigation or even no litigation and a continuous relationship. Where the process of mediation has started, an apology may have the desired effect of reaching a mutual agreement to settle the dispute.

However, within our pro-litigation system in South Africa that is not always achievable. The practice under the banner of our adversarial model is one of non-disclosure. Dialogue or open communications between the healthcare provider and the patient are discouraged even in those instances where doctors and nurses want to talk to their patient and/or family members. Any form of communication between the parties involved in litigation is viewed as a potential risk to a party's case.

The reluctance to talk may also be prompted by the practitioner's fear of bad publicity and accompanying reputational damages. Saying sorry or expressing an apology in whatever form, is viewed as an admission of liability. For those reasons, they are generally under starters' orders at the hospital and lawyers not to discuss anything. ${ }^{40}$ Showing empathy and talking about what had gone wrong is thus taboo.

The question may however, be begged: is the hospital authority, doctor, or specialist ethically obliged to disclose an error made by the hospital staff or by the doctor/specialist himself or herself? It appears that the authorities support the notion that disclosure of medical mistakes to patients need to take place. ${ }^{41}$ The rationale behind the principle of disclosure centres round consequentialism, ${ }^{42}$ deontology ${ }^{43}$ and virtue ethics. ${ }^{44}$ It also accords with the principles of taking responsibility ${ }^{45}$ and showing respect for the patient. ${ }^{46}$

38 Sohn and Bal "Medical Malpractice Reform: The Role of Alternative Dispute Resolution" 13 December 2011 Springer Clinical Orthopedics and Related Research http://www.ncbi.nlm.nih.gov.pmc/articles/PMC3314770/ (accessed 2016-02-16).

39 Marian http://www.randalltitus.co.za/?p=166.

40 Hobson "Big Challenge for Mediation in Medical Malpractice: Doctor Participation" 14 December 2010 http://blogs.wsj.com/health/2010/12/14/big-challenge-for-mediation-inmedical-malpractice-doctor-pa... (accessed 2016-02-05).

41 Moodley Medical Ethics, Law and Human Rights; A South African Perspective (2011) 67ff.

42 Moodley Medical Ethics, Law and Human Rights; A South African Perspective 68 states that after examining the risks and benefits to both patient and physician, the average patient is less likely to pursue legal action. An explanation had been given which satisfies the patient.

43 Ibid. The author contends that the duty to disclose is based on the fiduciary nature of the doctor-patient relationship. Trust dictates that the physician must be honest with the patient. Where for example, a swab is left behind and it comes to the doctor's knowledge he or she must own up to the mistake and correct it.

44 Moodley Medical Ethics, Law and Human Rights; A South African Perspective 68-69. Of a good or virtuous doctor, is expected a high degree of honesty and integrity. The virtuous doctor is also a caring medical practitioner who strives towards maintaining the concept of "primum non nocere", that is, "above all, do no harm" as provided for by the Hippocratic Oath. This includes disclosing mistakes.

45 Moodley Medical Ethics, Law and Human Rights; A South African Perspective 27 contends that being accountable for decisions taken and for one's actions as a doctor is consonant to the Kantian theory more particularly, Kant's famous invocation "Do your duty, even if the heavens fall!!!!!".

46 Moodley Medical Ethics, Law and Human Rights; A South African Perspective 52 states that respect in this context means not only respect for patient autonomy to reveal the truth after 
The outcomes of the disclosure have potential benefits to both to the patient as well as the doctor. Firstly, the uncertainty of the cause of the condition to the patient is cleared up with the patient respecting the doctor's honesty. Secondly, the process of disclosure opens up the potential for the doctor/physician or hospital authorities to make use of the peer review mechanisms alluded to above and take corrective action where possible. The doctor/physician or hospital staff may feel great relief and, having learnt from the mistake, get on with their respective careers.

However, the ultimate reduction of the risk of future mistakes depends quite heavily on the lesson learnt and good faith of the doctor and/or hospital. ${ }^{47}$ An apology and an undertaking to take corrective action may in mediation proceedings, encourage the parties to reach a mutually agreed settlement, with a system of explanation and reassurance of change, built into it. ${ }^{48}$ This is one of the areas in South Africa, where a paradigm shift is seriously indicated. ${ }^{49}$

What is perhaps needed is some kind of legislative protection to the healthcare provider after his or her apology and undertaking to take corrective action. Perhaps some kind of immunity alternatively a prohibition to pursuing cross-examination on that point where litigation cannot be averted can be built into the legal process, making all such type admissions on a without prejudice basis, coupled with a confidentiality agreement. Both the United States of America ${ }^{50}$ and Australia ${ }^{51}$ have successfully introduced legislation regulating the immunity process.

\section{(vi) Introducing mediation as an oversight mechanism}

One of the means available to assist with reform in bringing about a paradigm shift in handling medical negligence cases is through the introduction of alternative dispute resolution mechanisms, including mediation. It will also go a long way to facilitate the timely disposal of cases at a cost affordable by the parties to the litigation. ${ }^{52}$ The early exchange of information and the narrowing of the issues in dispute results in cases being more amenable to resolution by mediation. ${ }^{53}$ Both our Constitution ${ }^{54}$ and our

making a diagnosis but also revealing mishaps or errors that have been made in treating the patient. See in this regard the HPCSA's Guidelines for Doctors. S 1.2 regards truthfulness as a core value for good practice.

47 Hobson http://blogs.wsj.com/health/2010/12/14/big-challenge-for-mediation-in-medicalmalpractice-doctor-pa... 33; Liebman; "Medical Malpractice Mediation: Benefits, Gained Opportunities Lost" 201174 Law and Contemporary Problems 135, 136.

48 Binder Mediating Medical Malpractice Disputes: An Alternative to Tort Litigation (2001) 1921 www.cfcj-fcjc.org/sites/default/files/docs/hosted/17423-mediating_malpractice.pdf (accessed 2016-01-15).

49 MPS Paper on clinical medical negligence reform.

50 Berlin “Will saying 'I'm Sorry' Prevent a Malpractice Lawsuit?" 20061871 American Journal of Roentgenology www.ajronline.org/doi/full/10.2214/AJR.06.0110?rss=1\& (accessed 201707-15).

51 Australian Law Reform Commission "Effect of Apology on Liability" https://www.alrc.gov.au/publications/7-fault/effect-apology-liability (accessed 2017-07-15).

52 See the instructive article by Judge David Ipp "Case Management and Court-annexed Alternative Dispute Resolution" 1998 Consultus 49.

53 MPS Paper on clinical medical negligence reform. 
courts $^{55}$ identify the process. Perhaps, the recognition given to mediation may be found in its essential characteristics. There are many, but this paper chose to elucidate only the salient ones. They include inter alia the value of confidentiality of the proceedings. ${ }^{56}$ This will instil in the parties trust and confidence, as they are encouraged to speak freely and openly. Mediation is a voluntary process and parties may terminate the process at any stage. It must also be borne in mind, that if mediation fails, the parties are free to resort to or continue with litigation. Any offer, concession, or admission made during the mediation process is made without prejudice and may not be used later in a court or arbitration proceedings. Even an apology made during mediation cannot be used in court afterwards as evidence to prove liability.

Because mediation is viewed as optional, the following questions may be begged, is there a real need to introduce mediation? Proponents for litigation may argue that the process has for centuries, fulfilled its oversight role. Why now bring about changes? ${ }^{57}$ This paper will show that there are many benefits for all the parties involved.

\section{Benefits to the patient}

Some of the benefits to the patient and/or family include: in mediation, both parties sit down as equals with a trained professional mediator, sometimes a lawyer or a former judge or medical practitioner, to discuss what went wrong. Besides a sole mediator, the parties to the dispute could also agree on the appointment of two suitably qualified and experienced co-mediators from the fields of law and/or medicine. It is especially in matters that are more complicated where this is indicated. The parties involved in the dispute will seek to work out some settlement. The mediator is a neutral facilitator who guides the parties to reach a settlement. Besides avoiding a long drawn-out legal battle that is often settled on the doorsteps of the courts, mediation, depending on the willingness of the parties to co-operate, may produce

54 S 34 of the Constitution guarantees everyone the right to have any dispute that can be resolved by the application of the law decided in a fair public hearing before a court or, where appropriate, another independent and impartial tribunal or forum.

55 Although our jurisprudence is not rich in authority concerning mediation, there are a number of cases in which our courts have recognized the value of ADR and particularly mediation. See Lufuno Mphaphuli and Associates (Pty) Ltd v Andrews 2009 (6) BCLR 527 (CC) par 210; Chief Lesapho v North West Agricultural Bank 2000(1) SA 409 (CC) par 22; Giddey NO v JC Barnard and Partners 2007 (5) 525 (CC); Brownlee v Brownlee (Unreported Judgment on 25 August 2009 Brassey $A J$ in the South Gauteng High Court).

56 In Brownlee $v$ Brownlee supra the court per Brassey AJ stated the position as follows: "Mediation can produce reliable results in the most unpropitious of circumstances, especially when conducted by one of the several hundred people in this country who have been trained in the process. The success of the process lies in its very nature. Unlike settlement negotiations between legal advisors, in themselves frequently fruitful, the process is conducted by an independent expert who can, under conditions of the strictest confidentiality, isolate underlying interests, all the information to identify common ground and by drawing on his or her own and other knowledge, sensitively encourage an evaluation of the prospects of success in the litigation and an appreciate of the costs and practical consequences of continued litigation, particularly in the case of a loser." par 50.

57 Lerm "Litigation Not Only Answer" 23 March 2016 Herald Opinion 12. The writer besides giving compelling reasons for change, emphasised the moral and ethical duties on lawyers to give clients the option to using mediation to resolve the dispute. 
settlements far quicker than a full scale trial. Quick settlements through mediation or otherwise, is in line with societal interests for fair compensation following clinical negligence. Despite the aim for a quick settlement, the mediator is ethically and legally obliged to ensure that the award agreed to in terms of the settlement is not under settled. To this end, the mediator may rely on the services of medical experts and an actuary to derive at a reasonably acceptable amount.

Litigation, generally, poses a huge financial risk to the losing party. If the patient or family loses the case, they are at risk to pay the legal costs that could amount to millions. Mediation can help the doctor and the patient to see the problem from each other's perspective, which helps in finding a common solution. ${ }^{58}$ That is where the difference lies in the role of the mediator as opposed to the judge that presides over litigation. Whereas the mediator may probe to steer the parties in the direction of a mutual agreement, the judge dare not ask too many questions for fear of being accused of bias. It is often said that a trial judge who enters the arena too often, will have his vision clouded by the dust of the conflict.

Because mediation can be carried out much earlier, one does not need to have all the evidence assembled and go through all the stages of litigation before the dispute may lead to a settlement.

Besides the financial risk, patients or the family are emotionally charged, enduring great hardship, including anger, frustration and hurt. ${ }^{59}$ Achieving emotional closure through mediation is a great possibility. Aside from the saving on costs and getting the emotional stress behind them sooner, mediation takes place in an environment that is not as daunting as a court environment, and certainly, less threatening. The parties involved in the dispute are given an opportunity to express themselves more openly and honestly as to what had happened.

Here, lawyers need to consider the needs of the patient above their own. What is required is also a shift in a mindset. Whereas litigation places a great emphasis on the protection of rights, mediation, on the other hand, is more concerned about fulfilling the needs of the parties. That is where the lawyer needs to be sensitive and not becoming too personally involved in the dispute resolution process. Instead of becoming the litigator, rather act as a facilitator and be focussed on the needs and best interest of the client, which is often better served by the mediation process.

\section{Benefits to the healthcare provider}

To the healthcare practitioner who embraces the mediation process, the following benefits await them. Where litigation draws the attention to the healthcare provider who is often subjected to "a trial by media", mediation has the advantage that the process is conducted behind the veil of confidentiality. In that way, mediation maintains privacy and minimises the risk of the healthcare practitioner's professional reputation being destroyed

58 Ibid.

59 Botes 2015 De Rebus 23. 
through adverse publicity in the newspapers. ${ }^{60}$ In this way, the mediation process provides space for the litigants to talk safely in a confidential setting on the real issues between them. Once those issues are unearthed, the mediator can explore the needs of the parties and guide them towards different solutions.

Because medicine is not an exact science, the medical profession is frequently faced with inherent risks and dangers. Because healthcare practitioners are human beings and not robots, their fallibility in certain circumstances are understood. Their conduct does not necessarily constitute medical negligence. It is especially those matters, where the merits are not convincingly in favour of the claimant, that they should be subjected to mediation. The courts over time and only after hearing both parties will decide upon the matter. The judge hearing the matter is unlikely to draw a party's attention to the risks, strengths, and weaknesses of their respective cases. That position is different in mediation as the mediator may well do so for the party who is at risk so that he or she can make an informed decision.

\section{Benefits to the lawyers}

Although there is a general fear amongst lawyers that mediation will make an inroad into the earning capacity, causing them financial harm, there are benefits for them as well. Besides lawyers benefiting from becoming accredited mediators, their practices may also benefit in assisting the parties at the mediation sessions. Besides, because mediation is speedy, the process enables lawyers to work away from their caseloads much quicker than those litigated.

The process is less complex and assists to overcome prescription risks. Mediation also provides an opportunity for lawyers to assess the strengths and weaknesses of their cases at a very early stage and without for example the accumulation of complex pleadings or incurring costs of obtaining expensive medico-legal opinions which are usually at their risk when working on contingency.

It should not be forgotten that the role of the lawyer who represents the party to the dispute is not done away with in the mediation process. Although the legal representative does not play an active role as is the situation in court, he/she does assist the party they represent to prepare for the mediation and to participate effectively in the process.

In finalising matters much speedier, besides improving the cash flow position of a law firm, it enhances the lawyer's reputation with clients whose expectations are met and at greater cost effectiveness. ${ }^{63}$

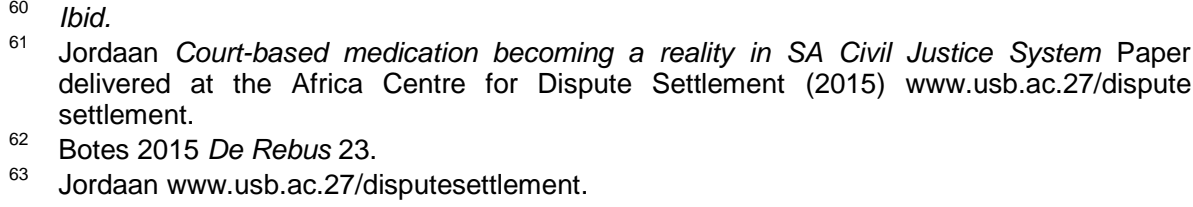




\section{Benefits to the Medical Protection Society and other insurers}

It is suggested that if reform measures are brought about as recommended herein before, the Medical Protection Society, as well as other insurance companies, will benefit. However, that depends very much on a change in their philosophical approach to handling medical negligence claims. Introducing and maintaining a system that ensures the expeditious payment of compensation for patients with meritorious claims at minimal costs to the underwriters will ensure that medical insurance claims can be sustained without unnecessary inroads being made in funding. Here mediation will be of great assistance and the process should be embraced by the protection societies and insurers.

\section{Other benefits}

An overarching benefit that mediation may bring to the legal landscape in South Africa also includes its creativeness in settling matters, often in favour of claimants as well as others who may benefit. ${ }^{64}$ To this end, three examples can be used.

> Creating employment for a spouse of a cancer patient who was formerly employed by the hospital but died under circumstances where the hospital may have been negligent in missing a lesion that its staff ought to have picked up. That of course depends on the skill required for the position and whether the spouse possesses that skill. Here, one may think more in terms of unskilled or semi-skilled workers. It further depends on whether the hospital wants to fill the existing vacant position.

> A hospital acknowledging a shortcoming of an essential procedure and undertaking to adopt the procedure and to make it part of its risk assessment.

A healthcare provider acknowledges the claimant's situation and shows empathy for the trauma that he or she is experiencing. ${ }^{65}$

\section{CONCLUSION}

Our healthcare system in South Africa is under siege so much so that if the challenges that we face are allowed to continue, those highly specialised medical professionals, particularly in the private sector, face extinction. Various extraneous factors have been identified in this paper that are possible causes for the position that we are in. The abuse of litigation by some lawyers has impacted heavily on healthcare budgets. Consequently, what is mooted in this paper is the necessity for a paradigm shift in the way the medico-legal community deals with medical negligence disputes. The

64 Allen "A New Way to Settle Old Disputes: Mediation and Healthcare" http://www.medicolegalsociety.org.uk/articles/mediationandhealthcare.pdf.

65 For examples of creative settlements through mediation see the recorded cases studies encountered in the United Kingdom http://www.effectivedisputeresolutions-le-uk/civilcommercial-mediation-services-personal-injury-clinical-negligence- disputes. 
situation is not unique to South Africa. Elsewhere around the world, other jurisdictions once faced similar challenges where, after much consideration, reform measures were put in place to deal with issues impacting on sustainable healthcare systems.

This paper suggests that we in South Africa need to learn from the modus operandi of those countries that brought about reform. Public interests dictate that we need to focus our attention on addressing those challenges that adversely impact on the medico-legal society as well as the broader community. By considering and introducing some of those measures identified in this paper, we may just move in the right direction and so prevent a catastrophe. 